\title{
Evaluation of bond strength between normal concrete and high performance fiber reinforced concrete (HPFRC)
}

\author{
Nur Adibah Ayuni Abd Malek 1,*, Khairunnisa Muhamad ${ }^{1}$, Mohd Zulham Affandi Mohd \\ Zahid $^{1}$, Nur Ain Hamiruddin ${ }^{1}$, Norrazman Zaiha Zainol ${ }^{1}$, Norhaizura Yahya ${ }^{1}$, Nurulashikin \\ Bahaman $^{1}$, and Nurfaraheen Mohd Ramli ${ }^{1}$ \\ ${ }^{1}$ Faculty Civil Engineering Technology Universiti Malaysia Perlis (UniMAP), 02100 Padang Besar, \\ Perlis, Malaysia.
}

\begin{abstract}
High Performance Fiber Reinforced Concrete (HPFRC) has been proposed to be used as a repair material for the deterioration of concrete structure since its very low porosity that leads to a low permeability and high durability. This characteristic makes it suitable for rehabilitation and retrofitting reinforced concrete structures or for as a new repair material. The bond strength between HPFRC and old concrete should have a good bond strength, thus surface preparation method and curing method can help strengthen the bond strength between HPFRC and normal concrete. This paper was performed to study the effect of surface preparation and curing method on the bond strength between HPFRC and normal concrete. In this study, three surface preparations were prepared: sandblasting, grooved and drill hole. Then, the curing methods that were performed in this study are ambient curing and water curing. The tests that were conducted to evaluate the bond strength between HPFRC and normal concrete are slant shear test and splitting tensile test. The result from this study shows that sandblasting gave the highest bond strength result between normal concrete and HPFRC. For the curing method, water curing gives the highest bond strength between normal concrete and HPFRC.
\end{abstract}

\section{Introduction}

Concrete becomes a major construction material for most building constructions nowadays. Deterioration of concrete becomes a serious problem. It is very costly and takes time and uses a lot of resources such as sand, aggregates, ordinary Portland cement and water. By replacing a deteriorated concrete with the same normal concrete strength is not effective in light of the fact that similar issues will continue happening later on if another approach is not taken. The bond strength between the damaged and repair concrete is supposed to have a good bond strength to guarantee a full structural collaboration between those damaged and repair concrete. A more practical alternative is to use High Performance Fiber Reinforced Concrete (HPFRC) as a repair material since its very low porosity leads to low permeability and high durability. This characteristic makes it suitable to repair and retrofit reinforced concrete structures (RCS) [1].

\footnotetext{
* Corresponding author: adibah.malek@gmail.com
} 
High Performance Fibre Concrete (HPFRC) is a high strength concrete combined with steel fibres. HPFRC shows a high compressive strength of more than $60 \mathrm{MPa}$, this high compressive strength was obtained by mixing a well-defined type of cement, superplasticizer, steel fibre and it a coarse aggregate was replaced with sand [2]. The properties of HPFRC which are high strength and low permeability that can lead it to have a good bond strength between normal concrete and HPFRC make it suitable to be a repair material [3]

Surface preparation method and curing method can help strengthen the bond between the normal concrete and UHPFRC. Surface preparation gives the best bond strength result [4]. Surface preparation or surface roughening has proved that this method can help strengthen the bond strength between damaged concrete and the new repair material concrete [5] The rougher the surface treatment is, the higher the bond strength between the normal concrete and HPFRC [6]

Besides, curing also can improve the ultimate compressive strength, enhance resistance to scrapes and reduce surface dusting. Curing is a method used to enhance the hydration of cement and control the temperature of the concrete and control the movement of moisture into the concrete, thus that will lead to better strength of concrete [6]. A previous study shows that steam curing is not applicable to be applied for in-situ concreting process, steam curing is more practical for precast processes [7]. Therefore, curing methods that are applicable for in-situ processes are ambient curing and water curing. Thus, the aim of this research is to study the effect of three different surface preparation methods (sandblasting, grooves, drill holes) on the bond strength between normal concrete and HPFRC and the effect of two different curing methods (ambient temperature, water curing) on the bond strength between normal concrete and HPFRC.

\section{Experimental procedure}

\subsection{Normal concrete and HPFRC}

The Department of Environment (DOE) mix design method was used to design normal concrete. In this study, characteristic strength of normal concrete is $30 \mathrm{MPa}$ at 28 days. Normal concrete contains Ordinary Portland Cement with a cement strength class of 42.5, fine aggregate, coarse aggregate with maximum size $20 \mathrm{~mm}$ and water cement ratio of 0.5 . The slump value for normal concrete is between $60 \mathrm{~mm}-180 \mathrm{~mm}$. Table 1 show the mix proportion of normal concrete. The normal concrete specimen used consists of $100 \mathrm{~mm}$ $\mathrm{x} 100 \mathrm{~mm} \times 300 \mathrm{~mm}$ prismatic beams for the slant shear test and $100 \mathrm{~mm} \times 200 \mathrm{~mm}$ cylinders for the splitting tensile test. Cube specimen was used as the control sample for the compression test and had a size of $100 \mathrm{~mm} \times 100 \mathrm{~mm}$. The control sample has been tested and the result is $29.7 \mathrm{MPa}$ at 28 days.

Table 1. Mix proportion of normal concrete.

\begin{tabular}{|c|c|c|c|c|}
\hline Material & Course Aggregate & Fine Aggregate & Portland Cement & Water \\
\hline $\begin{array}{c}\text { Proportion }(\mathrm{kg}) \\
\text { for } 1 \mathrm{~m}^{3}\end{array}$ & 590 & 1090 & 470 & 235 \\
\hline $\begin{array}{c}\text { Proportion }(\mathrm{kg}) \\
\text { for } 0.041 \mathrm{~m}^{3}\end{array}$ & 24.19 & 44.69 & 19.27 & 9.64 \\
\hline
\end{tabular}

The mixture of HPFRC contains Portland Cement (CEM1), well graded sieve of fine aggregates, densified silica fume, steel fiber, poly-carboxylate ether based (PCE) superplasticizer and water. The type of cement that has been used in this study was type 
CEM1 with strength class 52.5R. Fine aggregate is divided into two sizes of 150-300 and $300 \mu \mathrm{m}-600 \mu \mathrm{m}$. Steel fiber used in this study has two types of length, $14 \mathrm{~mm}$ and $6 \mathrm{~mm}$. The diameter for both steel fibers is $0.55 \mathrm{~mm}$. The amount of steel fiber added into a concrete mixture is $0.5 \%$ of the concrete volume. Table 2 shows the mix proportion of HPFRC.

Table 2. Mix Proportion of HPFRC.

\begin{tabular}{|c|c|c|}
\hline Constituent & Type of material & Proportion(ratio) \\
\hline \multirow{2}{*}{ Portland cement } & $\begin{array}{c}\text { Type CEM1- strength class } \\
52.5 \mathrm{R}\end{array}$ & 12 \\
\hline \multirow{2}{*}{ Fine aggregate } & $150-300 \mu \mathrm{m}$ & 0.6 \\
\cline { 2 - 3 } & $300-600 \mu \mathrm{m}$ & 1.5 \\
\hline Water & Potable water & 2.4 \\
\hline \multirow{2}{*}{ Superplasticizer } & $\begin{array}{c}\text { Poly-carboxylate ether based } \\
\text { (PCE) }\end{array}$ & 0.6 \\
\hline Silica fume & Micro Silica & 6.0 \\
\hline \multirow{2}{*}{ Steel fiber } & $6 \mathrm{~mm}$ & 1.21 \\
\cline { 2 - 3 } & $14 \mathrm{~mm}$ & 0.4 \\
\hline
\end{tabular}

\subsection{Sample preparation}

At the initial stage, normal concrete was casted into half of the mould (cylinder and prismatic beam). After 24 hours, a normal concrete specimen was demoulded and placed into a water tank to undergo a water curing process for 28 days. After the curing process, surface preparation methods (sandblasting, grooved, drill hole) were applied to the normal concrete specimen.

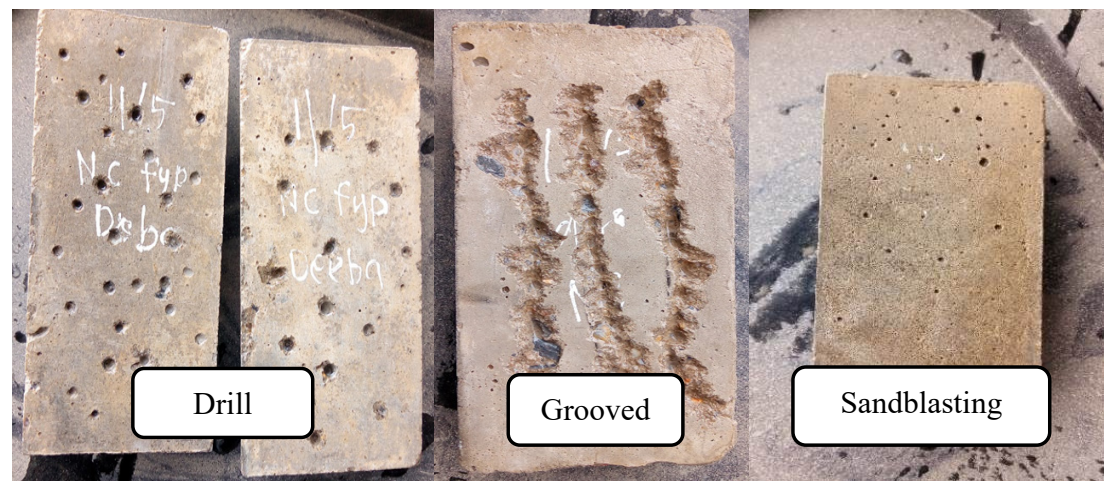

Fig. 1. Specimen with surface preparation.

After the surface preparation process, normal concrete was cured in a water tank for 24 hours before casting with UHPFRC. After 24 hours, the normal concrete specimen was put back into the mould (cylinder and prismatic beam) and casted with UHPFRC. Then, the concrete specimen was demoulded after 24 hours and was cured in the water tank for water curing and placed at room temperature for ambient curing. The curing process took place for 28 days before testing the concrete specimen. 


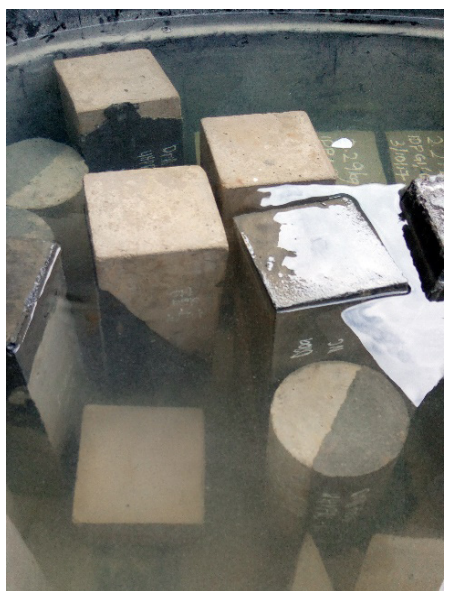

Fig. 2. Curing process of composite concrete.

\section{Testing}

\subsection{Slant shear test}

Slant shear test was as per specification of ASTM C882: Standard test method for bond strength of epoxy-resin systems using concrete by Slant Shear was used to investigate the bond strength between normal concrete and HPFRC. The HPFRC was casted and bonded to the normal concrete specimen on a slant plane inclined at an angle of $30^{\circ}$ from the vertical axis to form a $100 \mathrm{~mm} \times 100 \mathrm{~mm} \times 300 \mathrm{~mm}$ composite prism specimen.

The bond strength for the slant shear strength was calculated by dividing the maximum load by the bond area, which can be expressed as:

$$
S=P / A_{L}
$$

Where,

$\mathrm{S}=$ Bond strength (in $\mathrm{MPa})$

$\mathrm{P}=$ Maximum force (in $\mathrm{kN}$ )

$\mathrm{A}_{\mathrm{L}}=$ Area of the slant surface (in $\mathrm{mm}^{2}$ ); slant shear surface for this study $100 \times 100 / \sin 30^{\circ}$ $=20,000 \mathrm{~mm}^{2}$.

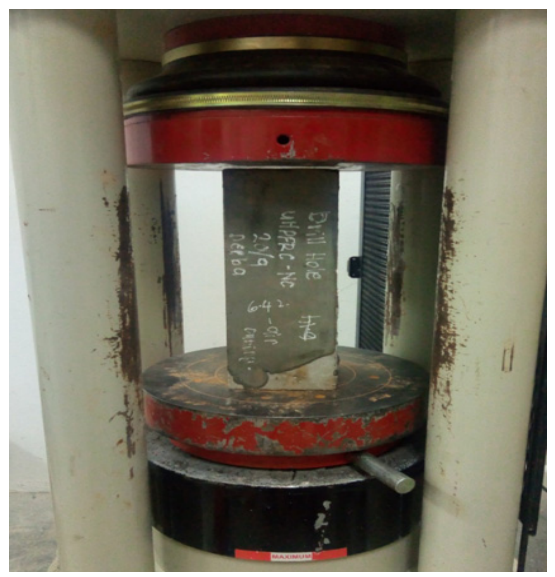

Fig. 3. Slant shear test specimen. 


\subsection{Splitting tensile test}

ASTM C496: Splitting Tensile Strength of Cylindrical Concrete Specimens has been referred for splitting tensile test. Splitting tensile test was used to investigate the bond strength and bond behaviour between the normal concrete and HPFRC. In this test, a cylinder with $100 \mathrm{~mm}$ diameter and $200 \mathrm{~mm}$ length was used as specimen.

Splitting tensile strength $(\mathrm{T})$ was calculated following the equation:

$$
T=2 P / \pi A
$$

Where,

$\mathrm{T}=$ Splitting tensile strength (in MPa)

$\mathrm{P}=$ Maximum experimental force (in $\mathrm{k} \mathrm{N}$ )

$A=$ Total area $\left(\right.$ in $\mathrm{mm}^{2}$ ) which is $200 \mathrm{~mm} \times 100 \mathrm{~mm}=20,000 \mathrm{~mm}^{2}$.

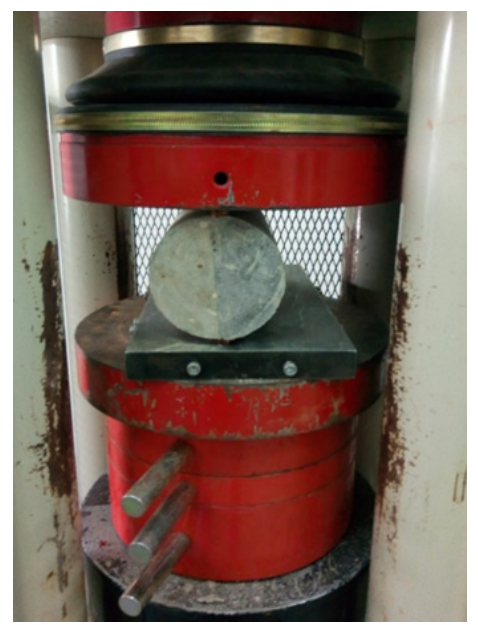

Fig. 4. Splitting tensile test specimen.

\section{Result and discussion}

\subsection{Slant shear strength}

Slant Shear Test was used to investigate the bond strength between normal concrete and HPFRC. In this test, a prismatic beam with size $100 \mathrm{~mm} \times 100 \mathrm{~mm} \times 300 \mathrm{~mm}$ was used. Table 3 shows the result of the slant shear strength of the composite specimen. 
Table 3. Slant shear strength.

\begin{tabular}{|c|c|c|c|}
\hline Surface treatment & Curing method & Average $\mathrm{S}_{\mathrm{av}}$ (MPa) & Failure mode \\
\hline \multirow{6}{*}{ Grooved } & \multirow{3}{*}{ Water curing (WC) } & \multirow{3}{*}{12.30} & $\mathrm{C}$ \\
\hline & & & $\mathrm{C}$ \\
\hline & & & $\mathrm{C}$ \\
\hline & \multirow{3}{*}{ Air Curing (AC) } & \multirow{3}{*}{10.64} & $\mathrm{C}$ \\
\hline & & & $\mathrm{C}$ \\
\hline & & & $\mathrm{C}$ \\
\hline \multirow{6}{*}{ Drill hole } & \multirow{3}{*}{ Water curing (WC) } & \multirow{3}{*}{10.90} & $\mathrm{~B}$ \\
\hline & & & $\mathrm{C}$ \\
\hline & & & $\mathrm{C}$ \\
\hline & \multirow{3}{*}{ Air Curing (AC) } & \multirow{3}{*}{9.29} & $\mathrm{~B}$ \\
\hline & & & $\mathrm{B}$ \\
\hline & & & $\mathrm{C}$ \\
\hline \multirow{6}{*}{ Sandblast } & \multirow{3}{*}{ Water curing (WC) } & \multirow{3}{*}{15.16} & $\mathrm{C}$ \\
\hline & & & $\mathrm{C}$ \\
\hline & & & $\mathrm{D}$ \\
\hline & \multirow{3}{*}{ Air Curing (AC) } & \multirow{3}{*}{11.42} & $\mathrm{C}$ \\
\hline & & & $\mathrm{C}$ \\
\hline & & & $\mathrm{C}$ \\
\hline
\end{tabular}

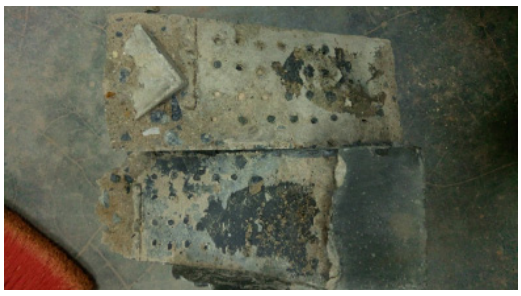

Fig. 5. Type B (Interfacial failure and substrate failure).

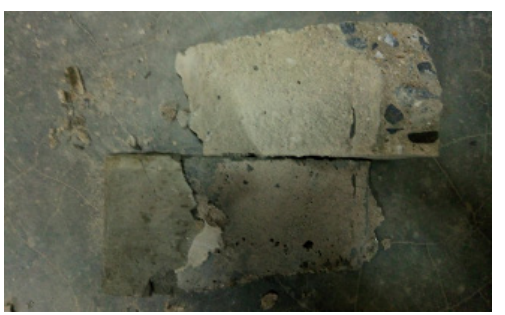

Fig. 6. Type C (Interfacial failure and substrate fracture).

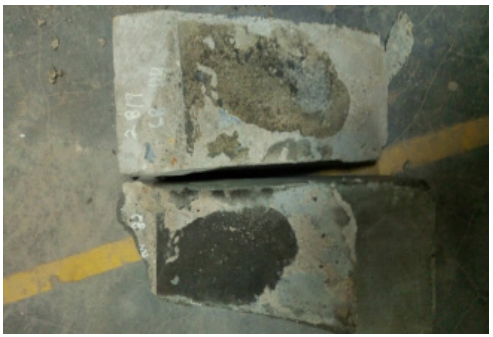

Fig. 7. Type D (Substratum failure).

From the result in Table 3, it shows that the sandblasting surface preparation method gives the highest shear strength as compared to the other two surface preparations [7]. The slant shear strength was affected by the roughened surface of the specimen. The more 
roughened the surface preparation is, the higher the bond strength between the normal concrete and UHPFRC will be. The bond strength of sandblasting is acceptable of the bond requirement at 28 days as specified by the $\mathrm{ACI}$ guideline.

For the curing method, water curing shows a higher result than ambient curing for each surface preparation. Water curing gives a higher shear strength because the water curing type allows more water to be made available for the hydration reaction of concrete cement paste since this method requires the concrete specimen to be immersed into water [8].

\subsection{Splitting tensile strength}

Split tensile strength was used to investigate the bond strength and bond behaviour between normal concrete and HPFRC. In this test, a cylinder with size $100 \mathrm{~mm} \times 200 \mathrm{~mm}$ was used. Results of the splitting tensile test were summarized in Table 4.

Table 4. Splitting tensile strength.

\begin{tabular}{|c|c|c|c|}
\hline Surface treatment & Curing method & Average $_{\text {av }}$ (MPa) & Failure mode \\
\hline \multirow{6}{*}{ Grooved } & \multirow{3}{*}{ Water curing (WC) } & \multirow{3}{*}{$\begin{array}{c}3.21 \\
\text { (Excellent) }\end{array}$} & $\mathrm{C}$ \\
\hline & & & $\mathrm{B}$ \\
\hline & & & $\mathrm{C}$ \\
\hline & \multirow{3}{*}{ Air Curing (AC) } & \multirow{3}{*}{$\begin{array}{c}1.95 \\
\text { (very good) }\end{array}$} & $\mathrm{B}$ \\
\hline & & & $\mathrm{B}$ \\
\hline & & & $\mathrm{B}$ \\
\hline \multirow{6}{*}{ Drill hole } & \multirow{3}{*}{ Water curing (WC) } & \multirow{3}{*}{$\begin{array}{c}2.67 \\
\text { (Excellent) }\end{array}$} & $\mathrm{B}$ \\
\hline & & & $\mathrm{B}$ \\
\hline & & & $\mathrm{B}$ \\
\hline & \multirow{3}{*}{ Air Curing (AC) } & \multirow{3}{*}{$\begin{array}{c}1.90 \\
\text { (very good) }\end{array}$} & $\mathrm{B}$ \\
\hline & & & $\mathrm{B}$ \\
\hline & & & $\mathrm{B}$ \\
\hline \multirow{6}{*}{ Sandblast } & \multirow{3}{*}{ Water curing (WC) } & \multirow{3}{*}{$\begin{array}{c}3.30 \\
\text { (Excellent) }\end{array}$} & $\mathrm{C}$ \\
\hline & & & $\mathrm{C}$ \\
\hline & & & $\mathrm{C}$ \\
\hline & \multirow{3}{*}{ Air Curing (AC) } & \multirow{3}{*}{$\begin{array}{c}3.02 \\
\text { (Excellent) }\end{array}$} & $\mathrm{C}$ \\
\hline & & & $\mathrm{C}$ \\
\hline & & & $\mathrm{C}$ \\
\hline
\end{tabular}

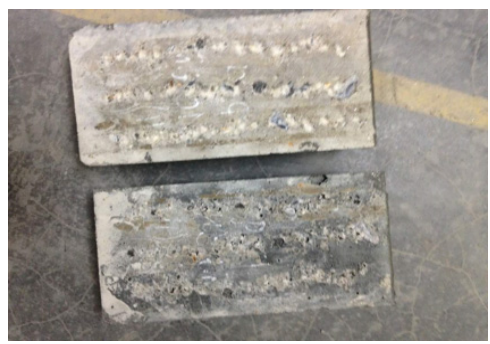

Fig. 8. Type B (Interface failure with partially substrate failure). 


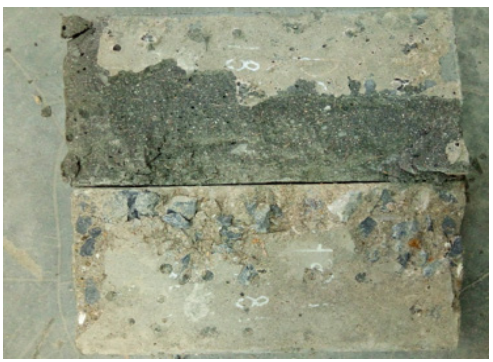

Fig. 9. Type C (Substratum failure).

The result obtained from Table 4 shows that sandblasting has the highest splitting tensile strength and drill hole has the lowest [7]. The result obtained proves that the more roughened the surface of the specimen is, the higher the bond strength will be. According to [7], the bond strength between normal concrete and HPFRC in this study is in the range of very good to excellent. Since the bond strength range is at very good to excellent, this means that the surface preparation method that has been investigated in this study is acceptable to be applied for repair work. For the curing method, water curing gives the higher strength for each type of surface preparation. It shows that water curing can help to strengthen the bond strength between HPFRC and normal concrete.

\section{Conclusion}

The study shows that slant shear test and splitting tensile test proved that the bond strength between normal concrete and HPFRC significantly depends on the surface preparation method of the specimen. The more the surface is roughened, the higher the bond strength will be. In this study, sandblast has the highest bond strength achieved. The same results were also achieved for slant shear which is also acceptable of the bond requirement at 28 days as specified by the ACI. At the same time, curing method also influences the bond strength of the composite concrete, where water curing gives the higher result compared to air curing.

This author acknowledges Faculty of Engineering Technology, Universiti Malaysia Perlis (UniMAP) for the lab facilities and the financial support received under Fundamental Research Grant Scheme (FRGS: Grant No. 900300105) provided by Ministry of Higher Education of Malaysia (MOHE).

\section{References}

1. Tayeh, B. A., Abu Bakar, B. H., Megat Johari, M. A., \& Voo, Y. L. (2013b). Utilization of ultra-high-performance fibre concrete (UHPFC) for rehabilitation a review. Procedia Engineering, 54, 525-538.

2. Kaïkea, A., Achoura, D., Duplan, F., \& Rizzuti, L. (2014). Effect of mineral admixtures and steel fiber volume contents on the behavior of high performance fiber reinforced concrete, $c$, 493-499.

3. Tayeh, B. A., Bakar, B. H. A., Johari, M. A. M., \& Lei, Y. (2012). Mechanical and permeability properties of the interface between normal concrete substrate and ultrahigh-performance fiber concrete overlay. Construction and Building Materials, 36, 538-548.

4. Bond, I., Between, S., \& Over, C. (n.d.). Improving Bond Strength Between Concrete Over Layers تناسرخلا ثاقبط نيب طبارتلا ةوق نيسحت. 
5. Askar, L. K., Tayeh, B. A., \& Bakar, B. H. A. (2013). Effect of Different Curing Conditions on the Mechanical Properties of UHPFC, 3.

6. Safritt, M. (2015). Bond Interface Strength between Ultra-High-Performance Concrete and Normal Concrete Presented by: (July).

7. Tayeh, B. A., Abu Bakar, B. H., Megat Johari, M. A., \& Voo, Y. L. (2013a). Evaluation of bond strength between normal concrete substrate and ultra-highperformance fiber concrete as a repair material. Procedia Engineering, 54(Farhat 2010), 554-563.

8. Gnanavenkatesh, S., Arun, M., \& Arunachalam, N. (2014). Effects on Concrete Strength by Three Types of Curing Methods, (6), 6-8. 